\title{
Global Changes of Malaysia toward New Economic Model: Review and Update
}

\author{
Parisa Maroufkhani ${ }^{1}$, Mohammad Nourani Dargiri ${ }^{2}$ \\ ${ }^{\prime}$ (Faculty of Economic and Administration, University Malaya, Malaysia) \\ ${ }^{2}$ (Graduate School of Management, Multimedia University, Malaysia)
}

\begin{abstract}
Malaysia has arrived at a defining moment in its development path. Malaysia's vision 2020 is impossible without considering the global changes. The aim of this paper is to review the five dimensions toward global changes and address the latest updates for this segment of economic growth in Malaysia. These five dimensions are leadership, governance, planet, profits/productivity and people. Malaysia's overall progress shows an upward trend, but global era is a highly competitive environment. In order to be an advanced nation among other competitors, more sophisticated policies have to be made to accelerate the growth process.
\end{abstract}

Keywords: Global changes, Malaysia, NEAC, New Economic Model. Introduction

\section{Introduction}

In the new world of competitive landscape, any entity must take note the issues and events that are happening beyond its territory. The late global financial crisis has considerably changed the advanced countries to grow in slower rate, on the other hand, pushed other countries to strengthen and upgrade their competitive advantages. This is what the chapter three in New Economic Model for Malaysia by National Economic Advisory Council (NEAC) is aimed to express.

Malaysia has arrived at a defining moment in its development path. Vision 2020 is impossible without considering the global changes. The previous models of growth brought three decades of prominent performance, introducing Malaysia as a landscape that provides its people high quality of health and education and becomes a major exporter in the global area. People have greater access to world-class and new technologies. Besides all these improvements, Malaysia stopped in the middle-income trap due to slower economy growth at last decade and not moving toward prosperity like it had before. The government must take action and make appropriate decisions in different segments to overcome this slow growth and move Malaysia to the next stage of development.

The global arena is considerably a place that Malaysia can make a parade to take advantage of the opportunities and lift itself to the next stage. In doing so, NEAC has keyed five key global trends in which Malaysia should deal with them and bring up Malaysia to the desired stage. These five keys are leadership, governance, planet, profits/productivity and people (Fig. 1).

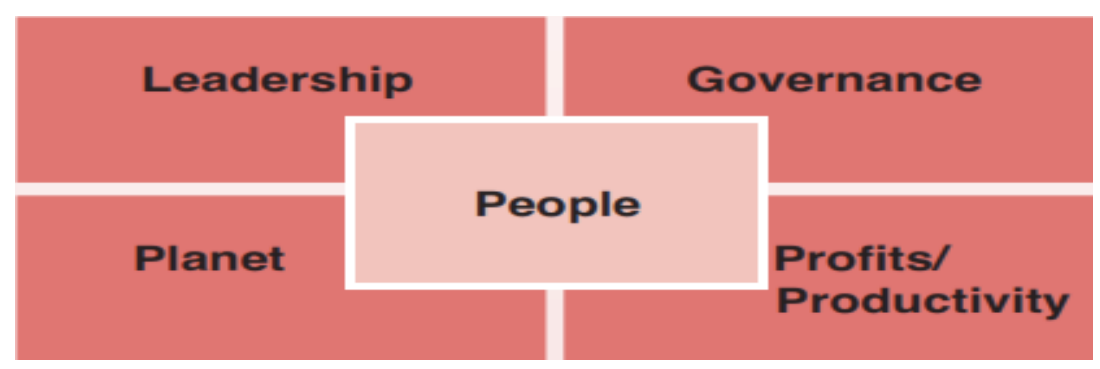

Figure 1: Five dimensions of global trends (Source: New Economic Model for Malaysia Part 1, NEAC) In this paper, we are going to review these five dimensions toward global changes and address the latest updates for this segment of economic growth in Malaysia. Each key will be evaluated separately in order to address the dimensions more in detail.

\section{Leadership, Changing Balance Of Power}

According to World Bank, the contribution of East Asia and Pacific region in world economy has increased three times in the 20-years period, reached up to $18 \%$ today, which emphasizes the importance of this area to the future growth of the world [1]. After the global financial crisis, the balance of power between nations has been subjected to change. It is now the time for newly emerging nations to take the leading role in hand and take the highest advantages of these created opportunities as much as possible. 
Fig. 2 shows the Nominal GDP percentage for three different groups. It is clear that after the global financial crisis how the balance of power has been changed between nations. The pre-crisis era is the time when G7 was dominance in its irresistible economic. After the financial crisis, its global GDP percentage decline below the 50\% in 2011 due to appearance of new emerging nations such as Brazil and Indonesia. The rate of decline in G20 is much lower than G7 because of those nations that are taking the lead in the competition, and its GDP shows $86 \%$ in 2010 and 2011. The new world growth engines accumulated in the group called BRICS, which comprises of countries such as Brazil, Russia, India, China and South Africa. Their substantial growth is clear in the Fig. 2 that increased up to almost $20 \%$ compare to only $9 \%$ in 2002. This is clearly emphasized the change of power into these newly emerging nations. Furthermore, it is determining who the leaders are in today world stage.

Fig. 3 indicates the nominal GDP for two emerging Southeast Asian countries; Indonesia and Malaysia. The prominent upward trend of GDP during 10 years period demonstrates the considerable development of Indonesia, which is continuing to strengthen its voice among G20 countries. In the line with Indonesian improvement, Malaysia also shows an upward trend in the last 10 years. Global financial crisis had affected Malaysian nominal GDP in 2009, but again continued to increase up to $0.4 \%$ in 2011.

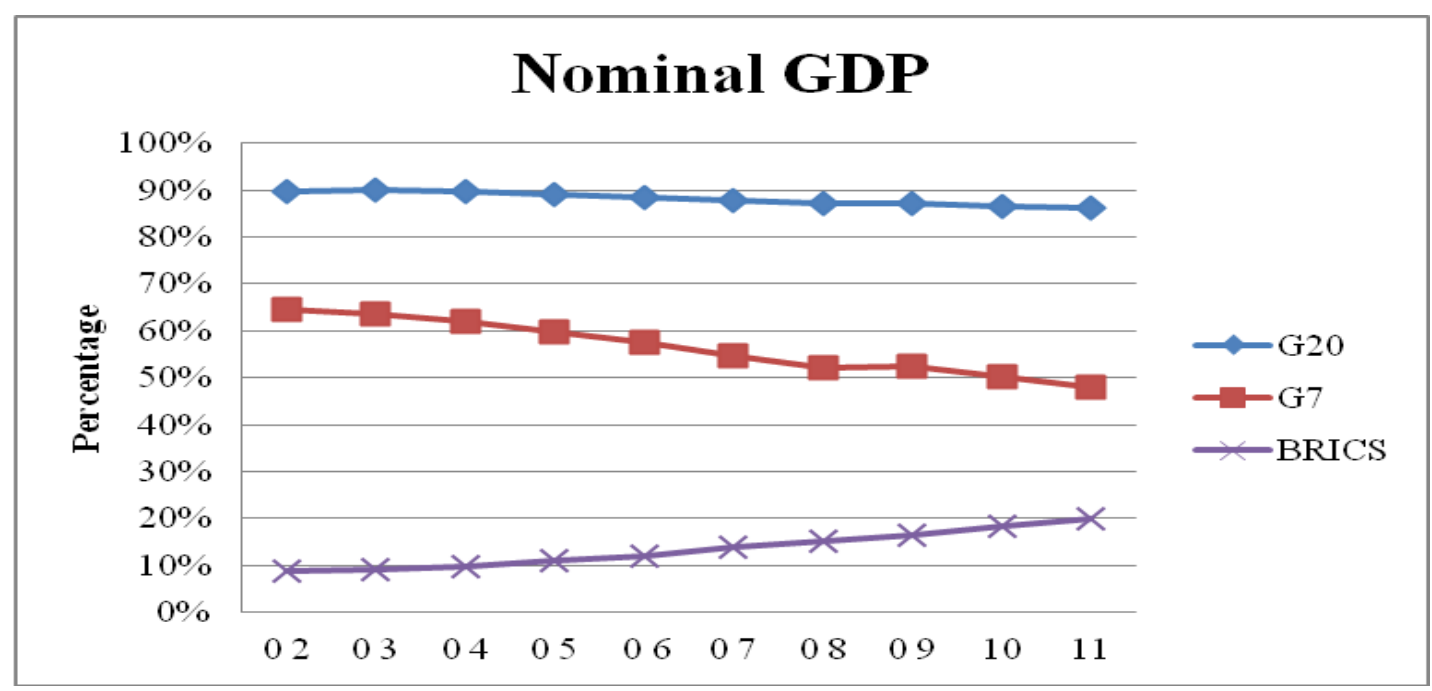

Figure 2: Comparison of Nominal GDP in 10 years between G20, G7 and BRICS (Source: World Bank)

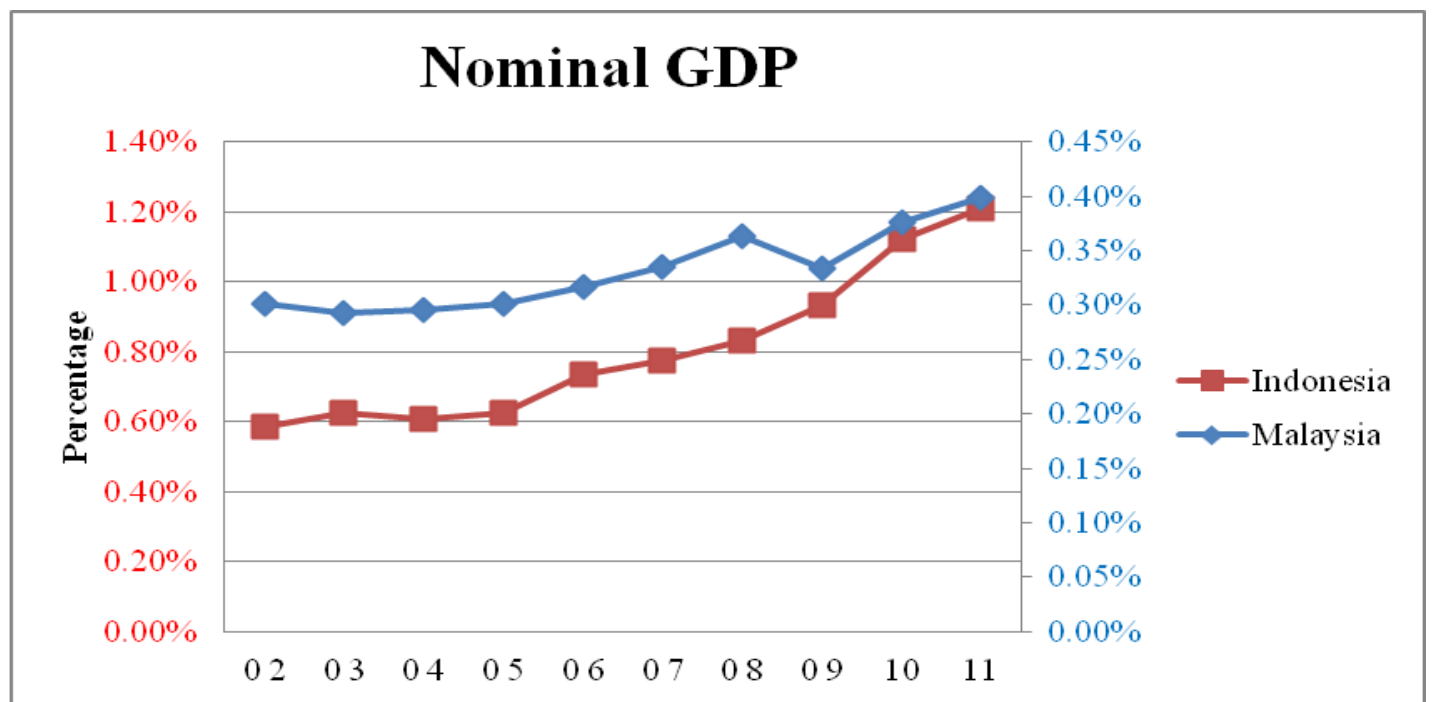

Figure 3: Comparison of Nominal GDP in 10 years between Malaysia \& Indonesia (Source: World Bank)

Leadership will belong to those nations that could take the most possible advantages of created opportunities. The definite fact is that none of the middle-income nations could compete in all fields against competitors. They realized that they must specialize in particular field and strengthen their competitive advantages in order to break the middle-income trap. Griffith [2] believes that while many middle-income nations in East Asia are starting to improve and having absorbed foreign knowledge, which resulted in increased 
production capabilities, much more needs to be done. Countries have their own privileges in which they can use to develop their strengths. Some may have natural resources, and some others may use people skills as competitive advantages. For instance, Korea is focusing on its technology skills; Singapore is raising its financial skills and resource-based countries such as UAE and Saudi Arabia are taking the advantages of their oil and gas. Many advanced countries are using their innovation plans to invest in different industries. Those countries with high quantity of human resources, such as China and India, are investing more in infrastructure.

Malaysia as a middle-income country has its own advantages in which trying to take the leadership in its particular field. Today, Malaysia considered as a global leader in electronic and electrical export and also more prominently palm oil. Furthermore, its tropical forest and marine reefs are among the best untouched natural resources which are famous and useful for many scientific researches. The electronic and electrical export contributed a substantial amount of Malaysia's total export and considered as a leading sector among Malaysian industries. Moreover, the major export destinations are US, China and Singapore [3].

The E\&E sector goes forward to be a significant contributor to export growth of Malaysia, especially by strong performance in segments such as hard disk drives and televisions [4]. Fig. 4 illustrates the Malaysia's Electronic and Electrical (E\&E) exports, which have been recognized as the leading sector in comparison to the total merchandise exports. It should be noted that the values have equalized using the U.S. Consumer Price Index (CPI). The trend shows an upward movement at last decade. Only after the financial crisis the Malaysian total merchandise and E\&E exports reduced to 143 and 41 billion dollar respectively. According to the annual report of Bank Negara Malaysia in 2011, the total merchandise exports increased up to $22.2 \%$ of total Malaysia's gross exports in 2010, whereas this figure was $13.3 \%$ in 2000 [4].

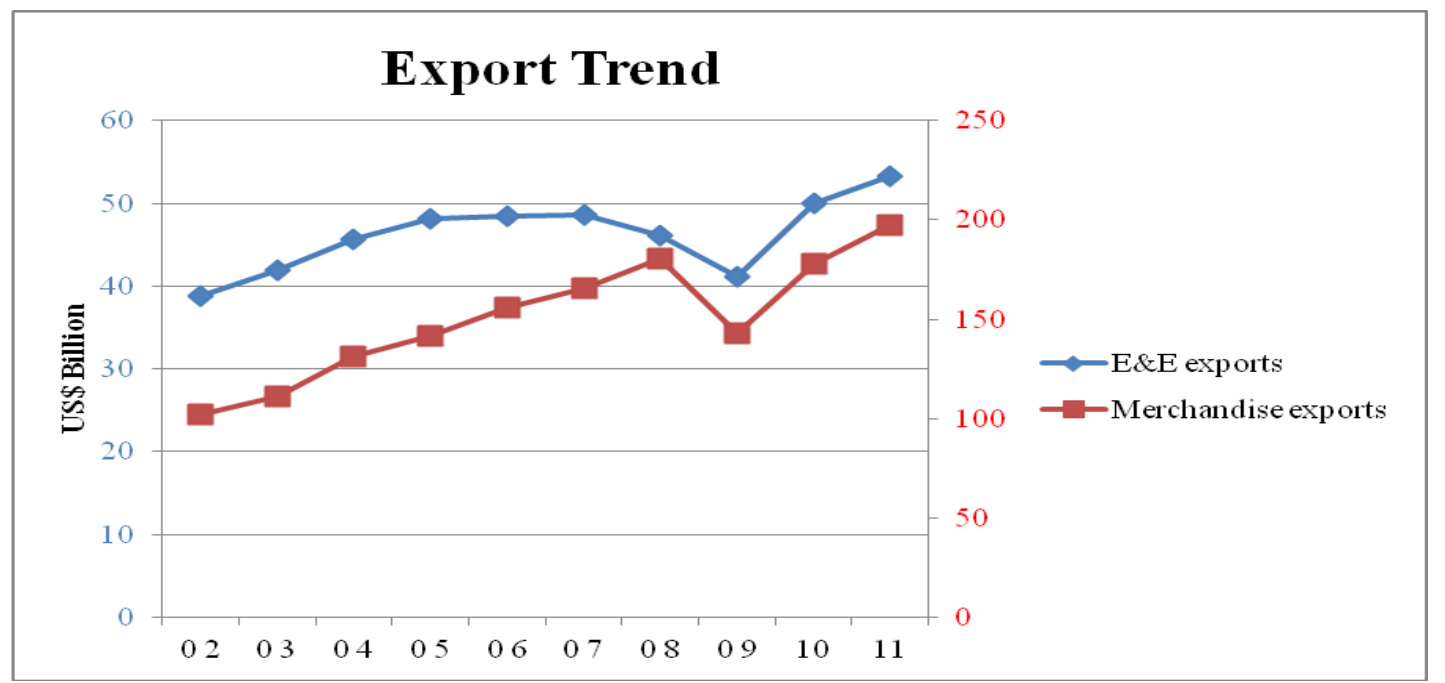

Figure 4: Malaysia's E\&E exports and total Merchandise exports over 10 years (Source: World Bank, UN Comtrade)

\section{Governance, The Primary Principle For Leadership}

As a primary start to achieve a successful leadership, governance at all levels plays a significant role in every nation. Private and public sector must work as a united body to accomplish high standard of transparency, fairness and inclusiveness. Corporate and public governance must do the best to adjust to the quickly changing environment because of intense competition, rapid technology growth and globalization. One of the key principles of the modern governance is not only having the cooperation between different parts of the network economies, but also creating competition between these parts to enhance the performance for every single segment. . Malaysia's 2020 perspective is to be the best among all, so must go beyond these standards.

The Worldwide Governance Indicators (WGI) project reports aggregate and individual governance indicators for six dimensions of governance consists of; Voice and Accountability, Political Stability and Absence of Violence, Government Effectiveness, Regulatory Quality, Rule of Law and Control of Corruption [5]. Based on the WGI indicators in Table 1, Malaysia is well above South-East Asia's norms in all dimensions, but still there is a wide gap between Malaysia and Organization for Economic and Co-operation and Development (OECD) nations that accepted the principle of free market. U.S. and U.K. stand on top of the OECD in most of the dimensions except political stability. The Malaysia's Voice and Accountability indicator shows a very weak performance compare to many other developed nations, which must be incased as an important issue and needs more to be done. In Fig. 5, Malaysia's Governance Indicators have presented from 2002 to 2011. It can be seen that how each indicator fluctuated over time. The advanced nations that are 
performing well in all dimensions show some particular attributes that Malaysia based on its 2020 vision must seek to address. These attributes are as follows; transparent, strategically focused, agile, responsive and inclusive.

Table 1: Governance Indicator (2011, Percentile rank, World Bank)

\begin{tabular}{|l|c|c|c|c|c|c|}
\hline & $\begin{array}{c}\text { Voice and } \\
\text { Accountability }\end{array}$ & $\begin{array}{c}\text { Political } \\
\text { Stability }\end{array}$ & $\begin{array}{c}\text { Government } \\
\text { Effectiveness }\end{array}$ & $\begin{array}{c}\text { Regulatory } \\
\text { Quality }\end{array}$ & $\begin{array}{c}\text { Rule of } \\
\text { Law }\end{array}$ & $\begin{array}{c}\text { Control of } \\
\text { Corruption }\end{array}$ \\
\hline Malaysia & 33.8 & 52.4 & 81.0 & 74.4 & 66.2 & 57.8 \\
\hline South East Asia & 30.0 & 41.2 & 47.5 & 45.3 & 40.0 & 36.2 \\
\hline OECD & 84.9 & 72.2 & 86.4 & 86.6 & 85.6 & 83.7 \\
\hline US & 85.9 & 63.7 & 88.6 & 91.9 & 91.1 & 85.8 \\
\hline Eastern Europe & 57.6 & 52.4 & 55.6 & 59.5 & 53.2 & 52.0 \\
\hline UK & 92.0 & 60.4 & 92.4 & 94.3 & 92.5 & 91.5 \\
\hline
\end{tabular}

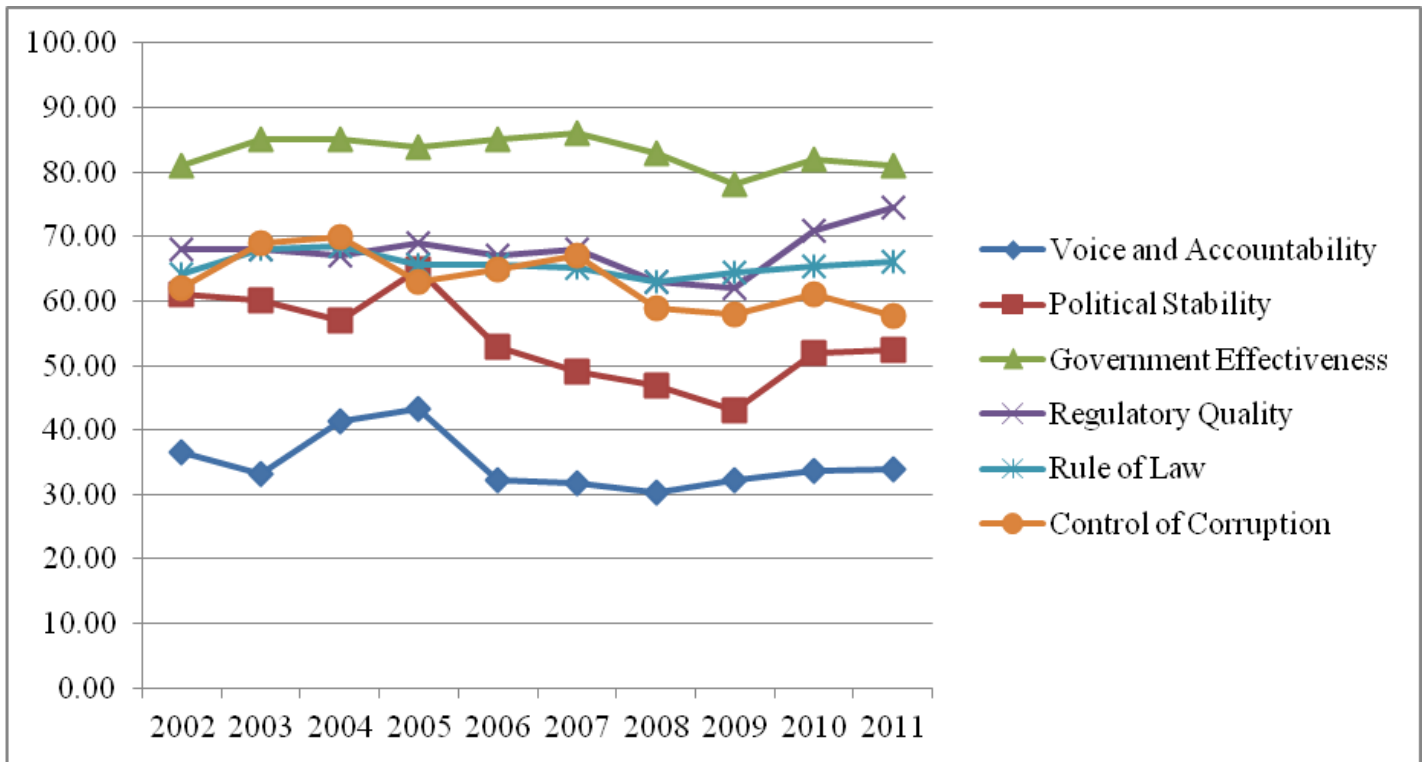

Figure 5: Malaysia's Governance Indicators over time (Source: World Bank)

In order to be a social accountable nation, the public sector must build a strong partnership with its civil society. The governance indicators released by World Bank will specify the quality of social accountability to some extents. The government must remove the barriers of trust and communication at different levels of society. The voice and accountability indicator measures by representative sources such as democracy index, freedom of association, transparency of government policy making, press freedom and so on. Although the Malaysia's voice and accountability indicator has increased in last four years, it is still a way behind the advanced nations. The growth in every single aspect of social accountability will raise the standard of living for civil society and as a result one pace closer to the vision 2020.

In developed nations and modern economics, minimal level of corruption considered as one of the key principles for governance. In comparison to other nations, Malaysia is performing better than South-East Asia and Eastern Europe and stands in yellow zone percentile meaning that it's higher than the average. The Performance Management \& Delivery Unit (PEMANDU) established in 2009 under the Prime Minister's department aims to oversee the social and economic transformation of Malaysia. Two important targets have been identified as to supervise the Government Transformation Programme (GTP) and the Economic Transformation Programme (ETP). According to ETP booklet, PEMANDU facilitated the 72 project commitments which created 298,865 jobs in a period of six months [6].

\section{Planet, Global Green Environment}

Being one of seventeen mega-diverse nations in the world, Malaysia is a place for a diverse network of coral reefs and globally substantial marine biodiversity. According to United Nations Development Programme or UNDP [7], different projects are in the line to strengthen the system of Malaysia's marine protected areas and also to ensure the sustainable and conservation use of marine biodiversity. However, more need to be done because there are other reasons that can ruin this natural heritage. For instance, Bio-fuels have been recognized as the key driver of the large number of deforestation in Brazil, Malaysia, and Indonesia, whereas those areas 
covered by forests have been substituted by palm oil and sugar cane [8]. Recently, the impact of climate change on environmental deterioration has become an international policy debate. Moreover, excess consumption and mindless dissipation of natural resources have increased the resource supply and resulted in reduction of nonrenewable resources. The sustainable growth of nations is depended on these natural resources; therefore, a professional management system is needed to overcome this issue.

The importance of Malaysia's natural resources is not only vital for Malaysia, but for the rest of the world. Preserving the natural rain-forest will reduce the world's carbon emission. The failure of managing the preservation will not only have the environmental damage, but also the sanctions may be imposed by other nations, which effect on Malaysia's export.

Malaysia's carbon dioxide per capita is higher than some of its neighbors such as Thailand and Indonesia (Fig. 6). Countries like U.S., Canada, and Australia show carbon dioxide emission higher than 16 tons per person. This is considered as a major challenge for Malaysia as its rate shows higher than the world average. According to Reuters' news, Prime Minister Najib Razak told Malaysia's government will offer credible cuts in its emissions of carbon dioxide at the Copenhagen climate change summit in a bid to halt global warming [9]. The promise has been made to reduction of $40 \%$ in Carbon dioxide by 2020 compare to 2005. Looking at the Malaysia's Carbon dioxide emission per capita in Fig. 7 over 10 years shows an upward trend until 2008. The rate was below five tons per person in 1999 compare to its current rate that is more than 7.5 tons. This commitment needs a very careful thoughtfulness, sophisticated planning and a perfect management system.

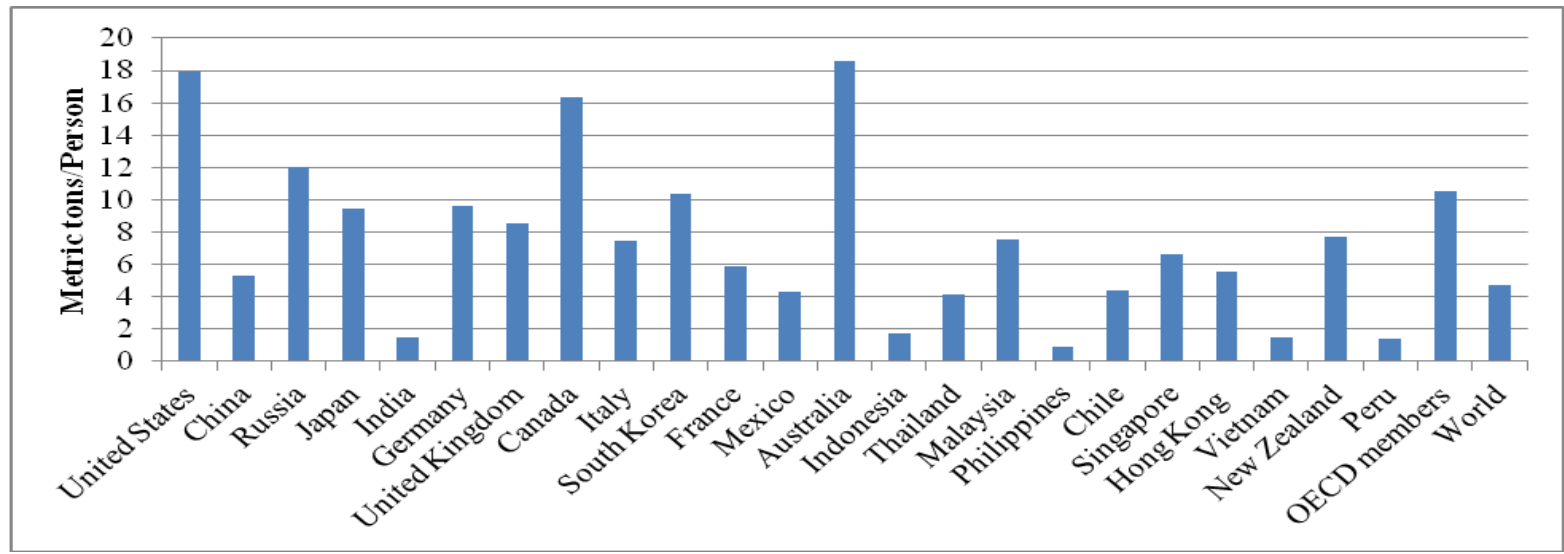

Figure 6: Carbon dioxide emissions per capita (2008; tons per person, World Bank)

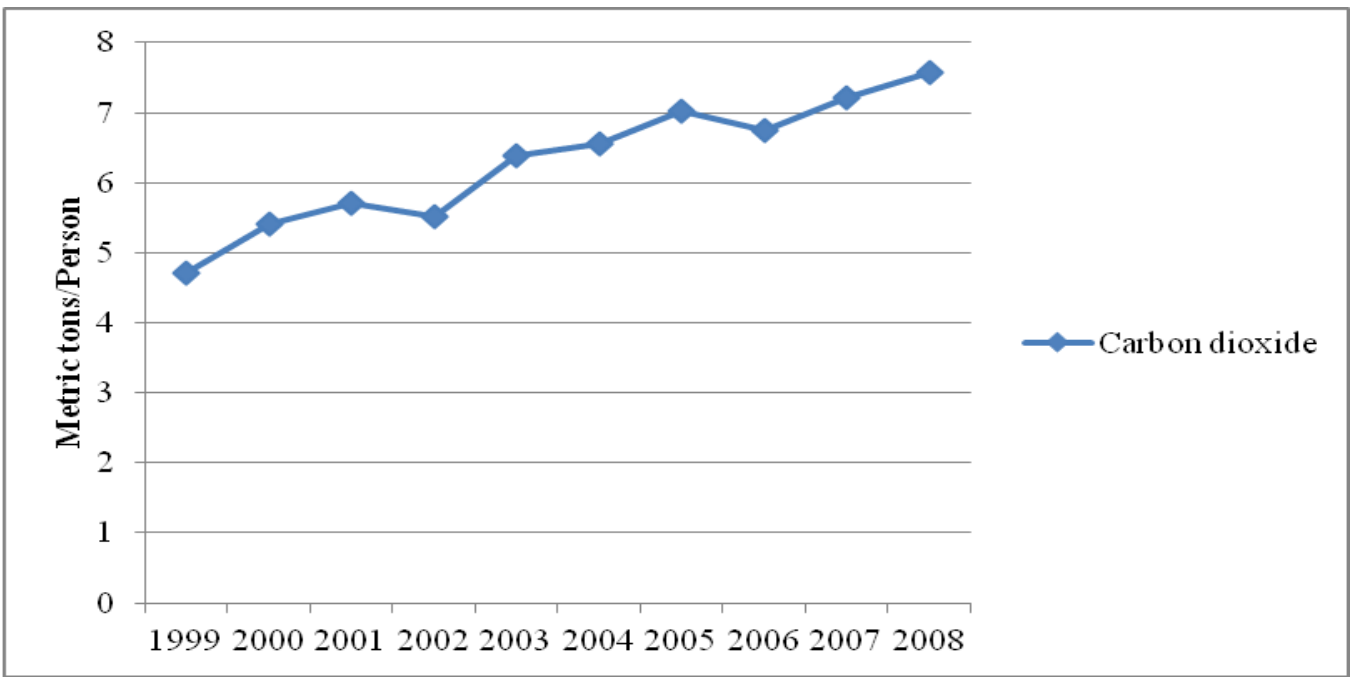

Figure 7: Malaysia's carbon dioxide emissions per capita (1999-2008; tons per person, World Bank)

The global attention to reduce Carbon dioxide will result in changes in manufacturing of goods into green product and using green technologies. Those nations that predict and get ready for these changes can take the leadership in this area. Malaysia as a green country can take the leadership in world and become a niche market for green industries and services. The Malaysian policy statement to fulfill the objective for reduces Carbon dioxide is that green technology shall be a driver to accelerate the national economy and promote sustainable development [10]. The Malaysian government initiatives toward green technology concentrated in 
four sections; Transportation, Energy, Building, Water \& Waste Management. One of the major objectives of going to green technology is to ensure sustainable development and conserve the environment for future generations of Malaysia. In doing so, there is a significant need to increase people education and awareness on green technology and promote its widespread for them and the whole world.

\section{Profits/Productivity, Large Versus Small And Medium Companies}

As mentioned earlier, the balance of power between nations has changed after the global financial crisis. Now, companies have to be smarter and faster in order to sustain in this competitive environment. There should be a solid relationship between big companies and Small and Medium Enterprises (SMEs) because SMEs are considered as a backbone of any economy. The importance of SMEs is highly significant because they are the most employment providers for larger companies. In new world, big companies could not sustain without the help of SMEs because every single job must be done by its professionals. Giant companies like GPMorgan or General Electric always acquire the smaller enterprises through acquisition or joint venture to do the subsidiary jobs. Therefore, giants will focus on main job or production to get larger and larger.

Profits and growth for any nations will come through the relationship between these giants and SMEs along with the increase in jobs for peoples, enhancement in quality of life and growth in investment. Many of the global giant companies are located in advanced nation with open and stable economies. According to Forbes 2000 , the biggest public company evaluation by market value in 2012, the majority of big companies are located in U.S., Japan and China (Fig. 8). Malaysia's giant companies increased up to 18 companies in 2012 compare to 2005, which was only 14 companies. Malaysia's big companies are still higher than the neighbor countries, but equal to Singapore's big companies.

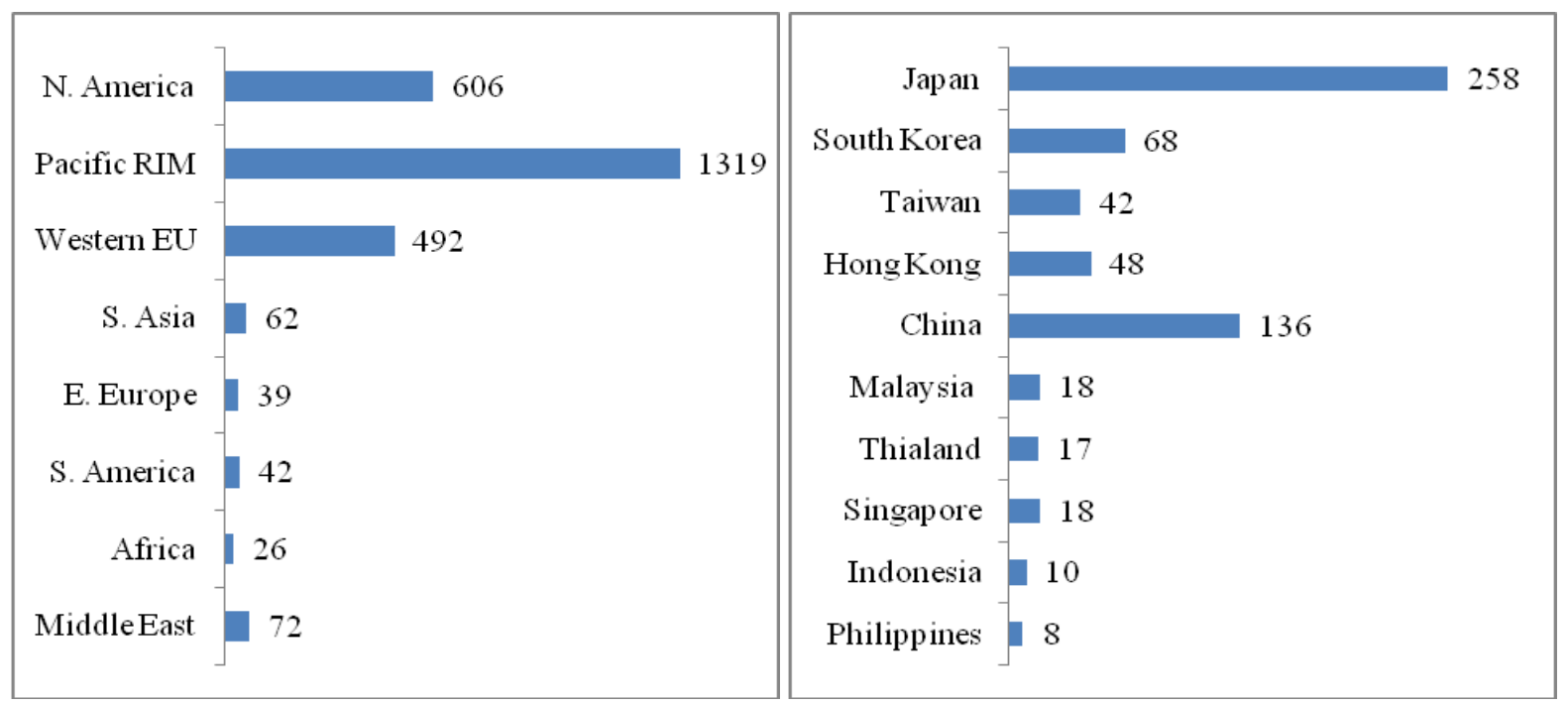

Figure 8 : Companies in Forbes 2000 by countries (April 2012, Number of companies, Forbes)

\section{People, The Most Valuable Asset}

All the dimensions of global changes would not work effectively without the people. Globalization accentuates the importance of people in nations and emphasizes that they are the most valuable asset. These are the people who run the economy of nations, so they must be flexible and competitive in national era as well as global era. Therefore, human resources need considerable attention because the destruction may happen between these valuable assets just like organizations.

In the first decade of the twenty-first century, furthermore, migration is getting more attention in public discourse than ever before. The migration in many countries has been a big issue since people are looking for a better quality of life. Aging societies always try to attract skilled people to their nations in order to rejuvenate their knowledge, skills and technologies. The competition has created between nations to attract the talented people from all around the world. People always want to leave in peaceful countries with greater equality, better regulations, and better opportunity of education for their children. Nations with healthy economy and environment could be able to attract the skilled people in a better way. Nations, who failed to provide the secure and healthy environment for their people, are in danger of losing their talents through outward migration (or emigration). Advanced nations give substantial attention to the personal security risks, because it will put all society in danger. Malaysia's emigration in 2010 was $5.3 \%$ of its population and top destination countries were Singapore, U.S., U.K., Australia and New Zealand [11]. According to World Bank report, 9.6\% of physicians trained in the country immigrated to other nations. In 2010, the number of immigrants was equal to $8.4 \%$ of the 
population, mostly from countries such as Indonesia, Philippines, China, Bangladesh, India and Thailand [11]. Global era is a highly competitive environment, and Malaysia must not only retain the skilled people through sophisticated policies, but also try to attract the global talented people who are looking for a better environment and quality of life. A study by Kaur [12] revealed that Malaysia and Thailand welcome low-skilled and highskilled people, but do not afford their settlement and Singapore is the single South-East Asian nation that gives the settlement to its high-skilled foreign people. Hugo [13] concluded that Malaysia's immigration of lowskilled people has increased significantly at last decade whereas there has been an outflow of Malaysian selective people of the higher-skilled groups.

Advanced nations recognized that having a more open and inclusive economy with a continually consultation with people will result in a better satisfaction, because they realize the people's needs and aspirations. Voice and accountability indicator of governance is a comprehensive index for relationship between people and government. Malaysia must work on this aspect of governance to have a better understanding of the people's needs and aspirations.

\section{Conclusion}

The late global financial crisis has created a great opportunity for developing nations to take one step further in their development path. Malaysia must take advantage of this created opportunity in order to be closer to vision 2020. The reviews and updates for five dimensions of global trends indicate the successes and failures in this competitive arena. The latest updates showed that Malaysia is recognized as a global leader in E\&E exports. Furthermore, the total nominal GDP of the country illustrates an upward trend. Governance, the primary principle for the leadership, is still the concern against Malaysia's development. Although, the Malaysia's Voice and Accountability indicator has increased in 2011 compared to 2008, but it is still far behind the other advanced nations. In Copenhagen meeting, Prime Minister Najib Razak promised to cut $40 \%$ of carbon dioxide emissions by 2020 compare to 2005. This promise needs more attentions considering that Malaysia's carbon dioxide emissions per capita have increased between 1999 until 2008. Growth of investment in Malaysia is visible when the number of giant companies has increased up to 18 companies. People are in the center of other global dimensions, meaning that all efforts through enhancement of other dimensions have been worth nothing without having people in company. Having an open and inclusive economy with a continuous consultation with people will result in a better satisfaction. Future Researches may compare the Malaysian global trends with other neighbor countries like Indonesia and Singapore in more details. Such comparisons will show the strengths and weaknesses of Malaysian economy. Furthermore, the need to research further and update regarding other aspects of economic growth is demanding.

\section{References}

[1] World Bank, East Asia and Pacific Economic Data Monitor, 2012, Available: http://www.worldbank.org/en/news/2012/10/08/eastasia-and-pacific-economic-data-monitor

[2] B. Griffith, Middle-Income Trap. Frontiers in Development Policy, World Bank Publications, 2011 , 39-42.

[3] MIDA, Industries in Malaysia, Electrical and Electronics Industry. Malaysian Investment Development Authority. 2012, Available: http://www.mida.gov.my/env3/index.php?page=ee

[4] BNM report, The Changing Structure of Malaysia's Exports, Economic Developments, 2011, Available: http://www.bnm.gov.my/files/publication/ar/en/2011/cp01_003_whitebox.pdf

[5] WGI, The Worldwide Governance Indicators (WGI) project reports, 2012, Available: http://info.worldbank.org/governance/wgi/index.asp

[6] UNDP, Sustainable Island Development, Conservation and sustainable use of marine biodiversity in Malaysia, 2012, Available: http://www.undp.org.my/page.php?pid=103\&action=preview\&menu=main

[7] ETP, PEMANDU. Delivering Transformation., 2012, Available: http://etp.pemandu.gov.my/upload/ETP_Booklet.pdf

[8] T. O. McShane, P. D. Hirsch, T. C. Trung, A. N. Songorwa, A. Kinzig, B. Monteferri and M. Pulgar-Vidal, Hard choices: Making trade-offs between biodiversity conservation and human well-being, Biological Conservation, 2011, 144(3), 966-972.

[9] Reuters, Interview - Malaysia PM to offer CO2 reductions in Copenhagen, 2009, Available: http://in.reuters.com/article/2009/12/13/idINIndia-44679920091213

[10] EPU, Green Technology: a Driver towards Sustainable Development, 2010, Available: http://www.epu.gov.my/html/themes/epu/images/common/pdf/Green_Technology.pdf

[11] World Bank, Migration and Remittances, Malaysia, 2011, Available: http://siteresources.worldbank.org/INTPROSPECTS/Resources/334934-1199807908806/Malaysia.pdf

[12] A. Kaur, Migration matters in the Asia-Pacific region: immigration frameworks, knowledge workers and national policies, Migration and Integration in the Asia-Pacific Region, 2007, 9(2), 135-157.

[13] G. Hugo, Migration and Development in Malaysia. Asian Population Studies, 2011, 7(3), $219-241$. 